\title{
IDENTYFICATION AND ASSESSMENT OF OCCUPATIONAL HAZARDS IN THE WORKING ENVIRONMENT OF THE LASER CUTTER OPERATOR
}

doi:10.2478/czoto-2020-0015

Date of submission of the article to the Editor: 25/11/2019

Date of acceptance of the article by the Editor: 16/12/2019

\author{
Dr eng. Michal Palega ${ }^{1}-$ orcid id: 0000-0002-2779-431X \\ Dr eng. Marcin Krause ${ }^{2}$-orcid id:0000-0002-9934-1539 \\ ${ }^{1}$ Czestochowa University of Technology, Poland \\ 2Silesian University of Technology, Poland
}

\begin{abstract}
The purpose of this article was to identify occupational hazards at the laser cutter operator's workplace and to assess occupational risk. The article also indicates the basic requirements for the analyzed workplace. Research methods included: observation of the workplace (using a checklist), interviews with the employer, selected employees and a health and safety specialist, as well as analysis of the company's internal documents. The occupational risk assessment carried out at work using the Risk Score method showed that there are many different risk factors for accidents or diseases related to the work performed at the position of the laser cutter operator. However, thanks to the preventive measures applied, they are in the analyzed workplace at an acceptable (acceptable) level.
\end{abstract}

Keywords: occupational exposure of employees, work environment, occupational risk assessment, laser cutter operator, occupational health and safety (OHS)

\section{INTRODUCTION}

The basic way to prevent accidents and related diseases with the work performed is reliable identification of risk factors and carrying out occupational risk assessment (Papadopoulos at al., 2010). The effectiveness of the occupational health and safety policy implemented in the workplace depends on the quality of this assessment (Pacana, 2017; Peeters and Peng, 2015; Seifi Azad Mard et al., 2017). According to the definition contained in the Ordinance (Journal of Laws of 2003, No. 169, item 165, with amendments), occupational risk is the probability of occurrence of adverse events related to the work performed, and in particular the occurrence of adverse health effects of the employee as a result of exposure to occupational hazards occurring in the work environment or due to the way work is performed.

In view of the above, the process of occupational risk assessment should be understood as continuous and systematic monitoring of working conditions aimed at identifying current and potential occupational hazards that may be the cause of an accident, injury, deterioration of the employee's health or occupational disease. The 
work environment study process also makes it possible to identify the necessary preventive measures to limit or eliminate the adverse impact of work environment factors on employees (Arimbi et al., 2018; Dolegowski and Janczala, 2008; Ejdys et al., 2008; Niciejewska and Klimecka-Tatar, 2018; Wieczorek and Zukowski, 2014).

For the purposes of occupational risk assessment, a careful assessment should be carried outand a comprehensive assessment of the workplace in terms of (Krause, 2017; Wieczorek and Zukowski, 2014):

- dangerous, harmful and troublesome factors occurring in the workplace;

- potentially accidental events;

- health and safety at work both in the workplace and in the entire workplace;

- ergonomic conditions in the workplace.

The purpose of this article is:

- identification of occupational hazards at the workplace of the laser cutter operator on the basis of observation of the workplace, analysis of source materials of the company and the author's knowledge;

- conducting occupational risk assessment for a selected job using the Risk Score method and determining the overall level of occupational risk, including preventive measures used to ensure an acceptable level of occupational risk.

\section{METHODOLOGY OF RESEARCH - RISK SCORE METHOD}

The Risk Score method is a qualitative, indicator method for assessing occupational risk, which takes into account the following parameters (Pietrzak, 2002):

- possible consequences of the event, losses caused by the incident (S value);

- exposure to the hazard (E value);

- probability of occurrence of the incident ( $P$ value).

The risk value $R$ describes the expression:

$$
\mathrm{R}=\mathrm{S} * \mathrm{E} * \mathrm{P}
$$

The criteria for estimating individual risk assessment parameters are described in Tables $1-3$, while the criteria for assessing risk value are presented in Table 4.

Table 1

Assessment of potential effects of the hazard - S (Risk Score)

\begin{tabular}{|c|c|c|c|}
\hline \multirow{2}{*}{ Value $\mathbf{S}$} & \multirow{2}{*}{$\begin{array}{l}\text { Type of } \\
\text { effects }\end{array}$} & \multicolumn{2}{|c|}{ Description of losses } \\
\hline & & human & material \\
\hline 100 & $\begin{array}{l}\text { A major } \\
\text { disaster }\end{array}$ & Many fatalities & Over 30 million PLN \\
\hline 40 & A disaster & Several fatalities & From 10 to 30 million PLN \\
\hline 15 & Very big & Fatal Victim & From 1 to 10 million PLN \\
\hline 7 & Big & Severe bodily injury & From 30 thousand up to PLN 1 million \\
\hline 3 & Medium & Absenteeism at work & From 3 to 30 thousand PLN \\
\hline 1 & small & First aid & Below 3 thousand PLN \\
\hline
\end{tabular}

Source: (Pietrzak, 2002) 
Table 2

Assessment of exposure to the hazard - E (Risk Score)

\begin{tabular}{c|c}
\hline Value E & Description of exposure \\
\hline $\mathbf{1 0}$ & Constant \\
\hline $\mathbf{6}$ & Common (everyday) \\
\hline $\mathbf{3}$ & Occasional (once a week) \\
\hline $\mathbf{2}$ & Occasional (once a month) \\
\hline $\mathbf{1}$ & Minimal (several times a year) \\
\hline $\mathbf{0 , 5}$ & Insignificant (once a year) \\
\hline
\end{tabular}

Source: (Pietrzak, 2002)

Table 3

Assessment of probability of occurrence of the hazard - P (Risk Score)

\begin{tabular}{c|c|c}
\hline Value $\mathbf{P}$ & Description of probability & Chance[\%] \\
\hline $\mathbf{1 0}$ & Very likely & 50 \\
\hline $\mathbf{6}$ & Quite possible & 10 \\
\hline $\mathbf{3}$ & Not likely, but possible & 1 \\
\hline $\mathbf{1}$ & Only sporadically possible & $10^{-1}$ \\
\hline $\mathbf{0 , 5}$ & Conceivable & $10^{-2}$ \\
\hline $\mathbf{0 , 2}$ & Virtually impossible & $10^{-3}$ \\
\hline $\mathbf{0 , 1}$ & Only theoretically possible & $10^{-4}$ \\
\hline
\end{tabular}

Source: (Pietrzak, 2002)

Table 4

Interpretation of the risk level indicator - R (Risk Score)

\begin{tabular}{c|c|c|c}
\hline Value $\mathbf{R}$ & Risk category & Risk acceptability & Necessary actions \\
\hline $\mathbf{R}<\mathbf{2 0}$ & Very small & \multirow{2}{*}{ Acceptable } & Control recommended \\
\hline $\mathbf{2 0} \leq \mathbf{R}<\mathbf{7 0}$ & Small & & Control needed \\
\hline $\mathbf{7 0} \leq \mathbf{R}<\mathbf{2 0 0}$ & Medium & & I need improvement \\
\hline $\mathbf{2 0 0} \leq \mathbf{R}<$ & Big & \multirow{2}{*}{ Unacceptable } & $\begin{array}{c}\text { Immediate improvement } \\
\text { needed }\end{array}$ \\
\cline { 1 - 1 } $\mathbf{R} \geq \mathbf{4 0 0}$ & Very big & & It is advisable to stop work \\
\hline
\end{tabular}

Source: (Pietrzak, 2002)

\section{RESULTS}

The work of the laser cutter operator consists in performing activities related to cutting a wide range of materials, such as (Internal materials of the examined enterprise): steel (e.g. carbon, alloy, construction, quality, tool, wear-resistant, galvanized), 
stainless steel (e.g. stainless, heat-resistant, acid-resistant), non-ferrous metals and their alloys (e.g. aluminum, copper, titanium, brass), stone (granite, marble, conglomerate, sandstone), ceramics, gum, plastics, glass, wood-based, wood-like panels and other. The operator's stand is located in a production hall with the following dimensions: $30 \mathrm{~m}$; width $-12 \mathrm{~m}$; height $-9 \mathrm{~m}$. The building is heated by central heating installation and meets the requirements for minimum temperatures at physical work stations. The workplace is illuminated by daylight through trained wall surfaces and in the ceiling. Fluorescent lamps are additional lighting. The floor is even, non-slip, dust-free and without thresholds between rooms. Employees have access to full hygiene and sanitary facilities. Escape routes have been designated on the company's premises and marked with appropriate pictograms. Occupational risk assessment at the position of the laser cutter operator was carried out using the Risk Score method. Based on the developed hazard identification card, the workplace was analyzed in terms of actual and possible (potential) hazardous, harmful and onerous factors. Parallel with the identification of hazards an initial assessment of their potential effects and the time of exposure of the employee (exposure) was conducted, taking into account the ones used preventive measures (technical, organizational and human) in the plant. Next, as part of own research, individual risk parameters and their total value were estimated for each threat, taking into account the criteria described in tables $1-4$.

Tables $5-6$ present the results of measuring occupational risk assessment at the position of the laser cutter operator.

Table 5

Hazards identification as a laser cutter operator

\begin{tabular}{|c|c|c|c|}
\hline $\begin{array}{l}\text { Hazard } \\
\text { symbol }\end{array}$ & Name of hazard & Source of hazard & Effects of hazard \\
\hline $\mathrm{TH}-1$ & $\begin{array}{l}\text { Capture by moving } \\
\text { machine parts }\end{array}$ & Moving machine parts & $\begin{array}{l}\text { Injuries, injuries, limb } \\
\text { amputations, death }\end{array}$ \\
\hline $\mathrm{TH}-2$ & $\begin{array}{l}\text { A sharp impact and } \\
\text { fixed elements }\end{array}$ & $\begin{array}{l}\text { Sharp protruding parts of } \\
\text { machines, devices and } \\
\text { workpieces }\end{array}$ & $\begin{array}{l}\text { Bruises, bumps, skin } \\
\text { abrasions, cuts, cut limb } \\
\text { woundsand heads }\end{array}$ \\
\hline TH-3 & $\begin{array}{l}\text { Damp by the } \\
\text { machine }\end{array}$ & $\begin{array}{l}\text { Machines moving around the } \\
\text { production hall }\end{array}$ & $\begin{array}{l}\text { Severe injuries, sprainsand } \\
\text { fractures of the limbs, } \\
\text { crushing, head and spine } \\
\text { injuries, concussion, internal } \\
\text { organ injuries, disability, death }\end{array}$ \\
\hline TH-4 & $\begin{array}{l}\text { Crush by the } \\
\text { machine }\end{array}$ & $\begin{array}{l}\text { Machines moving around the } \\
\text { production hall }\end{array}$ & $\begin{array}{l}\text { Severe injuries, sprainsand } \\
\text { limb fractures, crushing head } \\
\text { and spine injuries, } \\
\text { concussion, internal organ } \\
\text { injuries, disability, death }\end{array}$ \\
\hline TH-5 & $\begin{array}{l}\text { Hit by falling } \\
\text { objects }\end{array}$ & $\begin{array}{c}\text { Storage items on racks, fall } \\
\text { of moved material }\end{array}$ & $\begin{array}{c}\text { Bruises, bumps, cuts, head } \\
\text { injuries, concussion, disability, } \\
\text { death }\end{array}$ \\
\hline TH-6 & $\begin{array}{c}\text { Fall at the same } \\
\text { level }\end{array}$ & $\begin{array}{l}\text { Spilled fluids (water, oils, } \\
\text { greases), cables, left behind } \\
\text { tools and materials in the } \\
\text { wrong place, general }\end{array}$ & $\begin{array}{c}\text { Bruises, bumps, skin } \\
\text { abrasions, cuts, sprains and } \\
\text { fractures of the limbs, head } \\
\text { injury }\end{array}$ \\
\hline
\end{tabular}




\begin{tabular}{|c|c|c|c|}
\hline $\begin{array}{l}\text { Hazard } \\
\text { symbol }\end{array}$ & Name of hazard & Source of hazard & Effects of hazard \\
\hline & & $\begin{array}{c}\text { disorder, obstructed } \\
\text { communication routes, } \\
\text { improper footwear worn by } \\
\text { the employee }\end{array}$ & \\
\hline TH-7 & Fall to a lower level & $\begin{array}{c}\text { Using the stairs, using the } \\
\text { ladder }\end{array}$ & $\begin{array}{l}\text { Bruises, bumps, skin } \\
\text { abrasions, cuts, sprains and } \\
\text { fractures of the limbs, head } \\
\text { injuriesand spine, internal } \\
\text { organ injuries, disability, death }\end{array}$ \\
\hline TH-8 & Noise & and landings & $\begin{array}{l}\text { Fatigue, headache, } \\
\text { problemswith concentration, } \\
\text { malaise, damage to the } \\
\text { hearing organ }\end{array}$ \\
\hline TH-9 & $\begin{array}{l}\text { Electromagnetic } \\
\text { radiation }\end{array}$ & $\begin{array}{l}\text { Electromagnetic radiation } \\
\text { generated by the cutting } \\
\text { plotter screen or control } \\
\text { computer }\end{array}$ & $\begin{array}{c}\text { Nervous system diseases, } \\
\text { skin redness, itchy rash, } \\
\text { cancer }\end{array}$ \\
\hline $\mathrm{TH}-10$ & Laser radiation & $\begin{array}{l}\text { Laser radiation generated by } \\
\text { the laser }\end{array}$ & $\begin{array}{c}\text { Damage to the retina of the } \\
\text { eye, thermal damage to the } \\
\text { skin, erythema }\end{array}$ \\
\hline $\mathrm{TH}-11$ & Electric shock & $\begin{array}{l}\text { Faulty electrical installation, } \\
\text { use of faulty devices } \\
\text { and power tools }\end{array}$ & $\begin{array}{l}\text { Burns, paralysis, disorders of } \\
\text { the organs of the nervous, } \\
\text { respiratory, circulatory } \\
\text { systems, loss of } \\
\text { consciousness, death }\end{array}$ \\
\hline $\mathrm{TH}-12$ & $\begin{array}{l}\text { Changing weather } \\
\text { conditions }\end{array}$ & $\begin{array}{l}\text { Unloading or loading of } \\
\text { materials, objects outside } \\
\text { the production hall }\end{array}$ & Colds, flu, pneumonia \\
\hline $\mathrm{TH}-13$ & Fire & $\begin{array}{l}\text { Fire, arson, short circuit, } \\
\text { improper storage of } \\
\text { flammable materials, non- } \\
\text { compliance with smoking } \\
\text { bans }\end{array}$ & $\begin{array}{l}\text { Body burns, soaking, } \\
\text { disability, death, disaster }\end{array}$ \\
\hline $\mathrm{TH}-14$ & Thermal burns & Hot workpiece parts & Irritationand skin burns \\
\hline $\mathrm{TH}-15$ & Allergies, allergies & $\begin{array}{l}\text { Means used to maintain } \\
\text { laser machine tools (e.g. oil, } \\
\text { grease, liquids for cooling } \\
\text { workpieces) }\end{array}$ & $\begin{array}{l}\text { Allergies, irritation of the } \\
\text { mucous membranes of the } \\
\text { eyes, throat, larynx, } \\
\text { headache, malaise, } \\
\text { intoxication }\end{array}$ \\
\hline $\mathrm{TH}-16$ & $\begin{array}{l}\text { Dynamic load on } \\
\text { musculoskeletal } \\
\text { system organs }\end{array}$ & $\begin{array}{c}\text { Manual transport of } \\
\text { materials, workpieces and } \\
\text { waste, performing cleaning } \\
\text { works }\end{array}$ & $\begin{array}{l}\text { Muscle and joint pains, } \\
\text { tendonitis, spinal } \\
\text { degeneration, limb cramps }\end{array}$ \\
\hline $\mathrm{TH}-17$ & $\begin{array}{l}\text { Static load on } \\
\text { musculoskeletal } \\
\text { system organs }\end{array}$ & $\begin{array}{l}\text { Embedding materials on the } \\
\text { template, entering data into } \\
\text { the control computer, } \\
\text { supervising the cutting } \\
\text { process }\end{array}$ & $\begin{array}{l}\text { Pain, musculoskeletal system } \\
\text { diseases, flat feet, varicose } \\
\text { veins, spinal curvatures }\end{array}$ \\
\hline TH-18 & Eye load & Work that requires accuracy, & Visual impairment, pain, \\
\hline
\end{tabular}




\begin{tabular}{c|c|c|c}
\hline $\begin{array}{c}\text { Hazard } \\
\text { symbol }\end{array}$ & Name of hazard & Source of hazard & Effects of hazard \\
\hline & & poor lighting & burning, tearing, conjunctivitis \\
\hline & & Somatic symptoms (e.g. \\
TH-19 & $\begin{array}{c}\text { Load on the } \\
\text { nervous system }\end{array}$ & $\begin{array}{c}\text { Employee interpersonal } \\
\text { relations } \\
\text { depression, problemswith } \\
\text { concentration, dizziness, } \\
\text { stomach upset, coronary } \\
\text { artery disease }\end{array}$ \\
\hline
\end{tabular}

Source: Own study based on own research

Table 6

Occupational risk assessment card as a laser cutter operator

\begin{tabular}{|c|c|c|c|c|c|c|}
\hline \multirow{2}{*}{$\begin{array}{l}\text { Hazard } \\
\text { symbol }\end{array}$} & \multirow{2}{*}{ Preventive actions } & \multicolumn{4}{|c|}{ Size of risk } & \multirow{2}{*}{ Risk category } \\
\hline & & $\mathbf{S}$ & $E$ & $\mathbf{P}$ & Risk & \\
\hline $\mathrm{TH}-1$ & $\begin{array}{l}\text { Designation of a zone for moving } \\
\text { machine elements, motion } \\
\text { sensors }\end{array}$ & 15 & 6 & 0.2 & 18 [VS] & $\begin{array}{l}\text { AcceptableControl } \\
\text { recommended }\end{array}$ \\
\hline TH -2 & $\begin{array}{lll}\begin{array}{l}\text { Use of } \\
\text { (clothing, }\end{array} & \begin{array}{l}\text { personal } \\
\text { gloves, }\end{array} & \begin{array}{l}\text { protection } \\
\text { footwear), }\end{array} \\
\text { caution } & & \end{array}$ & 3 & 6 & 3 & 54 [S] & $\begin{array}{c}\text { Acceptable } \\
\text { Control needed }\end{array}$ \\
\hline TH-3 & $\begin{array}{l}\text { Designation of machine movement } \\
\text { zones, marking communication } \\
\text { passages, compliance with the } \\
\text { principles of safe machine } \\
\text { operation, compliance with the } \\
\text { prohibition to stay in the danger } \\
\text { zone, caution }\end{array}$ & 15 & 6 & 0.5 & $45[S]$ & $\begin{array}{c}\text { Acceptable } \\
\text { Control needed }\end{array}$ \\
\hline TH-4 & $\begin{array}{l}\text { Designation of machine movement } \\
\text { zones, marking communication } \\
\text { passages, compliance with the } \\
\text { principles of safe machine } \\
\text { operation, compliance with the } \\
\text { prohibition to stay in the danger } \\
\text { zone, caution }\end{array}$ & 15 & 6 & 0.5 & $45[S]$ & $\begin{array}{c}\text { Acceptable } \\
\text { Control needed }\end{array}$ \\
\hline TH-5 & $\begin{array}{l}\text { Maintaining order and } \\
\text { arrangement in the workplace, } \\
\text { arranging materials and objects } \\
\text { in a stable manner, securing the } \\
\text { material (load) being handled, } \\
\text { caution }\end{array}$ & 15 & 6 & 0.5 & $45[S]$ & $\begin{array}{c}\text { Acceptable } \\
\text { Control needed }\end{array}$ \\
\hline TH-6 & $\begin{array}{l}\text { Keeping the workplace clean and } \\
\text { tidy, paying attention to spilled } \\
\text { liquids (water, oils, greases), } \\
\text { proper cable laying, not setting } \\
\text { communication routes, transport } \\
\text { routes without thresholds between } \\
\text { rooms, the use of shoes with non- } \\
\text { slip soles, the use of mats } \\
\text { and non-slip floor coverings, } \\
\text { caution }\end{array}$ & 7 & 6 & 1 & $42[S]$ & $\begin{array}{c}\text { Acceptable } \\
\text { Control needed }\end{array}$ \\
\hline
\end{tabular}




\begin{tabular}{|c|c|c|c|c|c|c|}
\hline \multirow{2}{*}{$\begin{array}{l}\text { Hazard } \\
\text { symbol }\end{array}$} & \multirow{2}{*}{ Preventive actions } & \multicolumn{4}{|c|}{ Size of risk } & \multirow{2}{*}{ Risk category } \\
\hline & & $\mathbf{S}$ & E & $\mathbf{P}$ & Risk & \\
\hline TH-7 & $\begin{array}{l}\text { Maintaining order and work } \\
\text { environment, using a functional } \\
\text { ladder and platforms, marking } \\
\text { platforms } \\
\text { and any unevenness, caution }\end{array}$ & 15 & 6 & 0.5 & $45[S]$ & $\begin{array}{c}\text { Acceptable } \\
\text { Control needed }\end{array}$ \\
\hline TH-8 & $\begin{array}{l}\text { The use of personal protection } \\
\text { (hearing protectors, if the NDN } \\
\text { exceeds } 85 \mathrm{~dB}(\mathrm{~A}) \text { ), the use of } \\
\text { efficient machinery and } \\
\text { equipment, and repair (or } \\
\text { replacement) } \\
\text { and maintenance of this } \\
\text { equipment, which generates } \\
\text { excessive noise, switching off } \\
\text { unnecessary noise generating } \\
\text { devices, conducting periodic } \\
\text { checks and measurements of } \\
\text { noise values }\end{array}$ & 7 & 6 & 0.5 & $21[S]$ & $\begin{array}{c}\text { Acceptable } \\
\text { Control needed }\end{array}$ \\
\hline TH-9 & $\begin{array}{l}\text { The use of monitors with reduced } \\
\text { emissions of electromagnetic } \\
\text { radiation, the use of anti-static } \\
\text { liners, the appropriate position of } \\
\text { the monitor, the use of breaks in } \\
\text { working with the computer }\end{array}$ & 7 & 6 & 0.2 & $\begin{array}{c}8.4 \\
{[\mathrm{BM}]}\end{array}$ & $\begin{array}{l}\text { AcceptableControl } \\
\text { recommended }\end{array}$ \\
\hline $\mathrm{TH}-10$ & $\begin{array}{l}\text { Protection, covers, safety locks } \\
\text { that prevent the machine from } \\
\text { starting, the use of personal } \\
\text { protective equipment, checking } \\
\text { the technical condition of the laser } \\
\text { machine, caution }\end{array}$ & 7 & 6 & 0.2 & $\begin{array}{c}8.4 \\
{[\mathrm{VS}]}\end{array}$ & $\begin{array}{l}\text { AcceptableControl } \\
\text { recommended }\end{array}$ \\
\hline TH-11 & $\begin{array}{l}\text { Compliance with the rules for the } \\
\text { safe operation of machinery, } \\
\text { equipment } \\
\text { and power tools, using only } \\
\text { efficient equipment and tools } \\
\text { powered by electricity, switching } \\
\text { off devices in the event of faulty } \\
\text { cables, sockets, etc., carrying out } \\
\text { repairs and maintenance of } \\
\text { electrical installations and power } \\
\text { tools by authorized employees, } \\
\text { conducting periodic inspections } \\
\text { and measurements of electrical } \\
\text { installation parameters, effective } \\
\text { protection against electric shock, } \\
\text { caution }\end{array}$ & 15 & 6 & 0.5 & $45[S]$ & $\begin{array}{c}\text { Acceptable } \\
\text { Control needed }\end{array}$ \\
\hline TH-12 & $\begin{array}{l}\text { Adapting clothing to the weather } \\
\text { conditions outside (protection } \\
\text { against excessive cooling or } \\
\text { overheating) }\end{array}$ & 3 & 3 & 3 & $27[S]$ & $\begin{array}{c}\text { Acceptable } \\
\text { Control needed }\end{array}$ \\
\hline
\end{tabular}




\begin{tabular}{|c|c|c|c|c|c|c|}
\hline \multirow{2}{*}{$\begin{array}{l}\text { Hazard } \\
\text { symbol }\end{array}$} & \multirow{2}{*}{ Preventive actions } & \multicolumn{4}{|c|}{ Size of risk } & \multirow{2}{*}{ Risk category } \\
\hline & & S & $E$ & $\mathbf{P}$ & Risk & \\
\hline $\mathrm{TH}-13$ & $\begin{array}{l}\text { Ensuring efficient fire protection } \\
\text { measures (fire extinguishers, } \\
\text { sensors, etc.), the use of shields, } \\
\text { starting the laser when there is } \\
\text { material in its path, compliance } \\
\text { with fire protection rules, marking } \\
\text { of areas at risk of fire, compliance } \\
\text { with related rules } \\
\text { with operation and storage of } \\
\text { flammable substances, strict } \\
\text { compliance with the smoking ban, } \\
\text { caution }\end{array}$ & 40 & 3 & 0.5 & $60[S]$ & $\begin{array}{c}\text { Acceptable } \\
\text { Control needed }\end{array}$ \\
\hline $\mathrm{TH}-14$ & $\begin{array}{l}\text { Use of personal protection (if } \\
\text { required), use of special tools for } \\
\text { removing workpieces, caution }\end{array}$ & 1 & 6 & 3 & 18 [VS] & $\begin{array}{l}\text { AcceptableControl } \\
\text { recommended }\end{array}$ \\
\hline $\mathrm{TH}-15$ & $\begin{array}{l}\text { Ensuring adequate ventilation in } \\
\text { the production hall, using only } \\
\text { known ones } \\
\text { and approved substances, } \\
\text { proceeding in accordance with the } \\
\text { material safety data sheets, every } \\
\text { leak cleaning, caution }\end{array}$ & 7 & 3 & 1 & $21[S]$ & $\begin{array}{c}\text { Acceptable } \\
\text { Control needed }\end{array}$ \\
\hline $\mathrm{TH}-16$ & $\begin{array}{l}\text { Compliance with the rules for } \\
\text { manual transport (lifting standards, } \\
\text { lifting technique), avoiding manual } \\
\text { lifting of objects, ensuring the } \\
\text { correct organization of transport } \\
\text { work, the employee adopting the } \\
\text { correct body posture, caution }\end{array}$ & 3 & 6 & 1 & 18 [VS] & $\begin{array}{l}\text { AcceptableControl } \\
\text { recommended }\end{array}$ \\
\hline $\mathrm{TH}-17$ & $\begin{array}{l}\text { The employee adopting the } \\
\text { correct body posture, providing } \\
\text { breaks at work for rest or rotation } \\
\text { of employees (in the case of } \\
\text { constant or frequent exposure), } \\
\text { performing relaxation exercises, } \\
\text { exercising caution }\end{array}$ & 3 & 6 & 1 & 18 [VS] & $\begin{array}{l}\text { AcceptableControl } \\
\text { recommended }\end{array}$ \\
\hline $\mathrm{TH}-18$ & $\begin{array}{l}\text { The use of appropriate lighting, } \\
\text { cleaning and maintenance of } \\
\text { lighting fittings, ongoing } \\
\text { replacement of used light bulbs } \\
\text { and fluorescent lamps, correct } \\
\text { orientation of the light source, } \\
\text { correct positioning of the } \\
\text { workplace, use of breaks in work } \\
\text { and care for proper eye hygiene }\end{array}$ & 3 & 6 & 0.5 & 9 [VS] & $\begin{array}{l}\text { AcceptableControl } \\
\text { recommended }\end{array}$ \\
\hline $\mathrm{TH}-19$ & $\begin{array}{l}\text { Responding to conflict situations, } \\
\text { active rest, anti-mobbing } \\
\text { procedure }\end{array}$ & 7 & 3 & 1 & $21[S]$ & $\begin{array}{c}\text { Acceptable } \\
\text { Control needed }\end{array}$ \\
\hline
\end{tabular}

Source: Own study based on own research 
The occupational risk assessment carried out at work showed that there are many different hazards at the position of the laser cutter operator. Based on the analysis of the data contained in Table 4, it can be concluded that the most severe effects associated with the loss of human health or life, as well as material losses will be the result of such events as: fire, being caught by moving machine parts, being hit or crushed by the machine, hit by falling objects, falling to a lower level, electric shock.

In turn, considering the exposure to the threat, in the author's opinion, most threats are characterized by frequent (daily) exposure. Occasional exposure may relate to such risk factors as: fire, changing weather conditions or stress on the nervous system.

Considering the next risk assessment parameter, which is the probability of occurrence of a specific threat, the highest level (i.e. practically possible) was estimated for the following threats: impact against sharp and stationary elements, changing weather conditions, thermal burns. In turn, the lowest probability of hazard occurrence was estimated for related events captured by moving machine parts, electromagnetic and laser radiation.

\section{CONCLUSION}

Based on the literature analysis and own research, the following conclusions and final statements can be formulated:

1. Occupational risk assessment is a measure of the level of safety in the workplace. Its primary goal is to ensure the safety and protection of both business assets as well as people's health and life.

2. Occupational risk assessment should be carried out for each workplace (and more broadly the place of work) taking into account all hazardous or harmful factors occurring or likely to occur in the work environment, as well as individual predispositions of employees (including pregnant and breastfeeding women), juvenile, disabled or elderly employees or employees with no experience).

3. The basis for conducting occupational risk assessment is the identification of threats, which requires the collection of a range of information regarding both the workplace and the workplace, as well as the requirements for employees and the scope of their activities. The source of this information can be: observation of the workplace (using a checklist), interviews with the employer and employees, analysis of company documents (disease record, accident documentation, measurements of harmful factors, workplace instructions, instructions of machinery and equipment manufacturers, safety data sheets) or specialized literature.

4. Workplace analysis allowed to indicate the basic tasks and activities performed by the laser cutter operator, which include: preparation of the workstation, setting parameters of the cutting process, supervising the operation of the laser machine tool, transporting materials to the workstation or their storage places, conducting machine inspections and their maintenance, detection of irregularities in the operation of the machine tool and removal of minor defects, maintaining cleanliness at the workplace.

5. Work as a laser cutter operator involves exposure of the employee to the occurrence of many risk factors for an accident or illness related to the work performed. However, the occupational risk assessment showed that due to the 
preventive measures applied they are in the analyzed workplace at an acceptable (acceptable) level. It is also worth emphasizing that so far no accidents at work have been reported in the workplace.

6. Maintaining the acceptable level of identified occupational hazards requires systematic control of technical and organizational security measures applied, as well as employee education and their caution in special situations. Because the lack or disregard of the preventive measures indicated in the risk assessment card will increase the likelihood of a work-related accident or illness and, consequently, increase the risk category, even to an unacceptable level.

\section{REFERENCES}

Arimbi, H.B., Puspasari, M.A., Syaifullah, D.H. (2018). Hazard identification, risk assessment and risk control in a woodworking company, IOP Conference Series: Materials Science and Engineering, 505, 1-8.

Dolegowski, B., Janczala, S. (2008). Praktyczny poradnik dla służb bhp [A practical guide for OHS services], Gdansk: ODDK.

Ejdys, J., Lulewicz, A., Obolewicz, J. (2008). Zarządzanie bezpieczeństwem $w$ przedsiębiorstwie [Safety management in the enterprise], Białystok: Bialystok Technical University.

Internal materials of the examined enterprise

Krause, M. (2017). Hazards and occupational risk in hard coal mines - a critical analysis of legal requirements, IOP Conference Series: Materials Sciences and Engineering, 268, 1-9.

Niciejewska, M., Klimecka-Tatar, D. 2018. Health problems among employees in small enterprises as a result of improper OHS management, MATEC Web of Conferences, 183, 1012, DOI: 10.1051/matecconf/201818301012

Pacana, A. 2017. Comparative occupational risk assessment in a CNC machine tool operator position, Production Engineering Archives, 16, 28-31, DOI: $10.30657 /$ pea.2017.16.06

Papadopoulos, G., Georgiadou, P., Papazoglou, C., Michaliou, K. 2010. Occupational and public health and safety in a changing work environment: An integrated approach for risk assessment and prevention, Safety Science, 48(8), October 2010, 943-949.

Peeters, W. Peng, Z. 2015. An Approach Towards Global Standardization of the Risk Matrix, Journal of Space Safety Engineering, 2(1), June 2015, 31-38.

Pietrzak, L. 2002. Ocena ryzyka zawodowego. Poradnik 139 [Occupational risk assessment. Guide 139], Warsaw: Law Library.

Rozporządzenie Ministra Pracy i Polityki Socjalnej z dnia 26 września 1997 r. w sprawie ogólnych przepisów bezpieczeństwa i higieny pracy (Dz. U. z 2003 r. Nr 169 , poz. 165, z późn. zm.) [Ordinance of the Minister of Labor and Social Policy of 26 September 1997 on general health and safety regulations (Journal of Laws of 2003, No. 169, item 165, with amendments)].

Seifi Azad Mard, HR, Estiri, A., Hadadi, P., Seifi Azad Mard, M. 2017. Occupational risk assessment in the construction industry in Iran, International Journal of Occupational Safety and Ergonomics, 3(4), December 2017, 570-577.

Wieczorek, S., Zukowski, P. 2014). Organizacja bezpiecznej pracy [Organization of safe work], Krakow-Tarnobrzeg: Tarbonus. 